\title{
Maintain Body Fitness in the pandemic with video tutorials Senam Cegah Covid19 (SCC19) with Nusantara Aerobic Nusantara University PGRI Kediri in 2020
}

\author{
Puspodari ${ }^{1}$, Moh. Nur Kholis², Septyaning Lusianti ${ }^{3}$, Setyo Harmono4, Dhedy Yuliawan ${ }^{5}$, \\ M. Yanuar Rizky ${ }^{6}$ \\ 1, 2, 3, 4, 5 Nusantara University PGRI Kediri \\ Email: 1Puspodari90@gmail.com, 2nurkholis88@unpkediri.ac.id, 3lusi.cyrena220986@gmail.com, \\ 4setyo.harmono@unpkediri.ac.id, 5dhedhy_07@yahoo.com, 6yanuar.rizky17@gmail.com \\ doi https://doi.org/10.36526/gandrung.v1i2.917
}

\begin{abstract}
Sport is a form of physical activity that is carried out in a planned and structured manner which in its implementation involves repetitive body movements to improve physical and spiritual fitness. Sport becomes an important thing and must be done by the community in the midst of a COVID-19 pandemic. Because sports activities can improve fitness and increase endurance so it can be ensured that immunity becomes strong as a defense against the virus that causes COVID-19. Conducting Physical Distancing is an appeal by the World Health Organization (WHO) which has changed the way we live everyday. Began to do the teaching and learning process, work, worship also exercise at home. When doing physical exercise it is recommended not to overdo it with high intensity. Because, it can interfere with health. Prevent Covid-19 (SCC-19) is a type of exercise that is intended to prevent covid-19 to improve fitness and endurance. SCC is expected to be an alternative way to maintain health, fitness and endurance. This activity was carried out by conducting a virtual demonstration with a video tutorial on the movement of the gymnastics created by SCC-19, which was exhibited by the Nusantara Aerobic team, Nusantara University PGRI Kediri. The target subjects of this activity are all sports activists. The results of this activity indicate that there is good enthusiasm from the total audience of 4,625.
\end{abstract}

Keyword: Nusantara Aerobic UN PGRI Kediri, Senam Cegah Covid-19 (SCC-19)

\section{Pendahuluan}

Pada saat wabah COVID-19 ini muncul seluruh aktivitas manusia dibatasi, termasuk kegiatan berolahraga di pusat kebugaran atau arena olahraga lainnya. Masyarakat dihimbau agar menerapkan seluruh kegiatan pembelajaran, bekerja, beribadah dan berolahraga dari rumah. Hal ini dilakukan guna membatasi penyebaran virus yang masif. Physical distancing merupakan himbauan organisasi Kesehatan Dunia (WHO) yang banyak merubah cara hidup kita sehari-hari. Walaupun dalam kondisi physical distancing, masyarakat dapat memanfaatkan berbagai aktivitas olahraga, karena aktivitas olahraga dinilai dapat meningkatkan kebugaran dan meningkatkan daya tahan tubuh sehingga dapat dipastikan bahwa imunitas menjadi kuat sebagai pertahanan melawan virus penyebab COVID-19. Menjaga kesehatan dengan olahraga di rumah menjadi opsi paling bijak, di saat gym dan pusat olahraga 
GANDRUNG: Jurnal Pengabdian Kepada Masyarakat ISSN: 2721-6136 (Online)

tutup karena merebaknya virus corona (Covid-19).

Menurut WHO (Giriwijoyo, 2012) sehat merupakan karunia Allah yang menjadi dasar dari segala nikmat dan segala kemampuan bergerak, bekerja dan berfikir, akan berkurang atau bahkan hilang dengan terganggunya kesehatan kita.

Olahraga senam menjadi opsi yang cukup menarik untuk dilakukan di rumah, misalnya aerobik. Biasanya, instruktur olahraga aerobik ada di hadapan kita selama sesi berlangsung. Namun, karena darurat virus corona membuat banyak orang memilih untuk tetap di rumah, maka instruktur online dijadikan pilihan saat pandemi. Ditinjau oleh dr. Karlina Lestari, olahraga senam aerobik juga bisa meredakan gejala depresi dan gangguan cemas, yang mungkin diakibatkan oleh virus corona.

Dalam beberapa studi, aerobik berhasil mengurangi gejala pada penderita depresi dan gangguan cemas. Mukholid (2004) berpendapat bahwa Kesegaran Jasmani ialah kemampuan dan kesanggupan untuk melakukan aktivitas atau kerja, mempertinggi daya kerja dengan tanpa mengalami kelelahan yang berlebihan. Setiap orang membutuhkan kebugaran jasmani yang baik agar dapat melaksanakan pekerjaan dengan efektif dan efisien tanpa mengalami kelelahan. Derajat kebugaran jasmani seseorang sangat menentukan kemampuan fisiknya dalam melaksanakan tugas-tugasnya sehari-hari. Selanjutnya Lutan (2001), menambahkan bahwa kebugaran jasmani (yang terkait dengan kesehatan) adalah kemampuan seseorang untuk melakukan tugas fisik yang memerlukan kekuatan, daya tahan dan fleksibilitas.

Pendapat lain juga datang dari Irianto (2004) yang menyatakan bahwa kesegaran jasmani adalah kebugaran fisik (physical fitness), yakni kemampuan seseorang melakukan kerja sehari-hari secara efisien tanpa timbul kelelahan yang berlebihan sehingga masih dapat menikmati waktu luangnya. Kesegaran jasmani adalah kemampuan atau kesanggupan fisik seseorang untuk melakukan tugasnya sehari-hari secara efektif dan efisien dalam waktu yang relatif lama tanpa mengalami kelelahan yang berarti (Depdikbud, 1996). Makin tinggi derajat kebugaran jasmani seseorang maka makin tinggi pula kemampuan kerja fisiknya. Manfaat latihan kebugaran jasmani yang utama adalah membuat tubuh menjadi lebih sehat dan bugar. Pengertian kebugaran jasmani sendiri sebetulnya adalah gerakan yang membutuhkan kerja otot sehingga tubuh akan membakar kalori. Aktif bergerak bukan hanya akan melunturkan lemak tubuh, melainkan juga menurunkan risiko depresi sehingga kualitas hidup juga akan meningkat.

Latihan kebugaran jasmani banyak pilihan dan bentuk olahraga yang cocok berdasarkan preferensi dan kondisi fisik masing-masing. Untuk dapat mencapai kondisi kesegaran jasmani yang prima seseorang perlu melakukan aktivitas fisik yang melibatkan komponen kesegaran jasmani dengan metode

Volume 1, Number 2, Juli 2020| 8 Maintain Body Fitness in the pandemic with video tutorials Senam Cegah Covid19 (SCC19) with Nusantara Aerobic Nusantara University PGRI Kediri in 2020

Puspodari, Moh. Nur Kholis, Septyaning Lusianti, Setyo Harmono, Dhedy Yuliawan, M. Yanuar Rizky 
GANDRUNG: Jurnal Pengabdian Kepada Masyarakat ISSN: 2721-6136 (Online)

latihan yang benar (Depdiknas, 2002). Salah satu olahraga masyarakat yang paling diminati adalah senam aerobik. Senam aerobik merupakan senam yang diisi oleh serangkaian gerakan yang dilakukan secara beriringan dalam waktu tertentu dan diiringi oleh irama musik. Selain efektif membakar kalori dalam tubuh, senam aerobik juga dirasa cukup menyenangkan untuk dilakukan karena lantunan musik yang menemani gerakan selama latihan membuat menjadi lebih bersemangat.

Menurut Kristono (Jonni, 2003) "Aerobik yaitu latihan yang bertujuan untuk meningkatkan kemampuan paru-paru, jantung, serta peredaran darah, dimana oksigen merupakan faktor utama pembangkit energy pada sel-sel tubuh." Gerakan demi gerakan pada senam aerobik bertujuan untuk melatih otot-otot tubuh, serta bermanfaat dalam meningkatkan aliran oksigen ke otot dan jantung. Dalam melakukan latihan fisik hendaknya tetap memperhatikan prinsip overload.

Menurut Sukadiyanto (2011) prinsip overload artinya beban harus sedikit di atas ambang rangsang. Sebab beban yang terlalu berat akan mengakibatkan tidak mampu diadaptasi oleh tubuh, bila terlalu ringan tidak berpengaruh terhadap peningkatan kualitas fisik, sehingga beban latihan harus memenuhi prinsip beban lebih. Senam aerobik merupakan olahraga yang banyak manfaatnya untuk tubuh, terutama sangat baik untuk kesehatan jantung. Senam aerobik dinilai sebagai salah satu olahraga yang cukup santai dan tidak membutuhkan terlalu banyak tenaga sehingga aman dilakukan oleh berbagai kalangan, baik wanita hamil dan orang tua.

Senam Cegah Covid-19 (SCC-19) merupakan jenis olahraga senam aerobik kreasi yang diperuntukan guna mencegah covid-19 guna meningkatkan kebugaran serta daya tahan tubuh. SCC-19 diharapkan menjadi cara alternatif untuk menjaga kesehatan, kebugaran dan daya tahan tubuh. Nusantara Aerobic Universitas Nusantara PGRI Kediri merupakan tim senam Universitas Nusantara PGRI yang memiliki prestasi lebih. Prestasi terakhir yang pernah dicapai tim Nusantara Aerobic adalah juara 1 Piala Kemenpora Senam SKJ Jadoel tahun 2019. Senam SSC19 diperagakan oleh 9 mahasiswa kemampuan siswa 20 anak dengan beraneka karakteristik anak. Gerakan senam Cegah Covid19 yang menarik diharapkan mampu menarik minat olahraga senam dari rumah guna meningkatkan imunitas dan kebugaran tubuh.

\section{Metode}

Melalui kegiatan senam Cegah Covid-19, masyarakat akan dapat terlibat langsung dalam mengikuti kegiatan senam dari rumah secara online melalui youtube. Kombinasi gerakan yang sesuai dengan aturan protokol kesehatan dalam pencegahan virus Covid-19 juga meningkatkan pemahaman masyarakat akan pencegahan virus Covid-19. Selain itu musik pengiring senam kreasi ini juga 
GANDRUNG: Jurnal Pengabdian Kepada Masyarakat ISSN: 2721-6136 (Online)

mempunyai daya tarik tersendiri sehingga audience lebih bersemangat selama mengikuti latihan. Senam Cegah Covid-19 ini dilakukan secara sistematis, terarah dan terencana sesuai . Saat melakukan olahraga fisik dianjurkan untuk tidak dilakukan secara berlebihan dengan intensitas tinggi. Sebab, hal tersebut bisa mengganggu kesehatan. Senam cegah covid19 sangat direkomendasikan untuk semua kalangan.

Metode dalam pelaksanaan pengabdian masyarakat ini menggunakan metode demonstrasi virtual pelaksanaan senam Cegah Covid19. Dalam pelaksanaan senam kreasi ini awali dengan gerakan pemanasan inti dan pendinginan yang disesuaikan dengan tema mencegah virus corona. Kegiatan ini diunggah di laman youtube yang bisa diakses secara online. Beberapa pihak yang terlibat diantaranya adalah dosen sebagai pelatih, pengabdi, dan observer, mahasiswa tim senam Nusantara Aerobik, dengan jumlah instruktur (peraga) sebanyak 9 mahasiswa. Kegiatan ini berlangsung selama 3 hari proses pendampingan. Proses pendampingan dilakukan secara virtual dengan latihan via zoom kemuan dilanjutkan koreksi gerakan tiap peraga dengan video individual kemudian terakhir pemantapan dan pelaksanaan.

\section{Hasil dan Diskusi}

Pelaksanaan kegiatan senam cegah Covid19 sudah dipersiapkan secara maksimal sesuai perencanaan yang ditetapkan melalui tahapan sebagai berikut: Tahapan pra pratik dilakukan dengan menyiapkan lingkungan/ruang dan media/ alat serta posisi tempat kegiatan senam yang akan dipergunakan oleh instruktur, tahap kegiatan awal dilakukan untuk instruktur mempersiapkan senam cegah covid-19. Tahap berikutnya mendemonstrasikan dengan rekaman video kemudian mengunggah video tutorial senam cegah covid-19 melalui akun youtube. Kegiatan senam cegah covid19 ini mendapat respon baik sebanyak 4.625 .

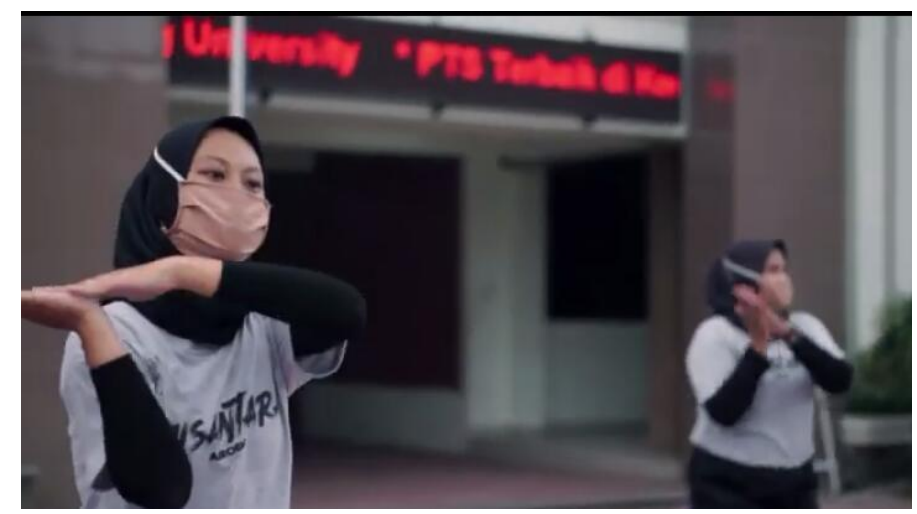

Gambar 1. Gerakan cuci tangan dalam senam cegah covid-19

Volume 1, Number 2, Juli 2020 | 10 Maintain Body Fitness in the pandemic with video tutorials Senam Cegah Covid19 (SCC19) with Nusantara Aerobic Nusantara University PGRI Kediri in 2020

Puspodari, Moh. Nur Kholis, Septyaning Lusianti, Setyo Harmono, Dhedy Yuliawan, M. Yanuar Rizky 
GANDRUNG: Jurnal Pengabdian Kepada Masyarakat ISSN: 2721-6136 (Online)

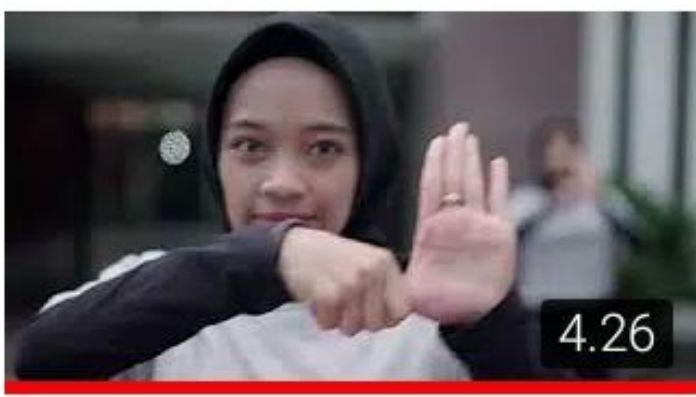

Senam Cegah Covid 19, Nusantara Aerobic

UNP Kediri

2 bulan yang lalu $\cdot 5,2 \mathrm{rb} \times \mathrm{d}$...

Gambar 2. Tampilan Awal pencarian di chanel youtube

Setiap orang yang memiliki kebugaran jasmani yang baik akan mampu melakukan aktifitas atau beban fisik yang dihadapi dalam kehidupan sehari-hari dan masih menyisakan tenaga untuk mengisi waktu luang.

Mengadakan demostrasi virtual senam cegah covid-19 sangat penting untuk dilakukan mengingat kebugaran jasmani diperlukan untuk menjaga imunitas tubuh. Berdasarkan hasil demonstrasi vrtual dan komentar di youtube, kegiatan senam cegah covid-19 ini sangat membantu masyarakat dalam proses peningkatan kebugaran jasmani dan lebih menginspirasi banyak kalangan dalam membuat senam kreasi untuk masyarakat sebagai bahan latihan fisik dari rumah.

\section{Kesimpulan}

Mengadakan demonstrasi vitual senam cegah covid-19 yang dilakukan selama 5 menit yang di arahkan oleh instruktur dengan variasi gerakan sesuai tema protokol kesehatan seperti mencuci tangan, menggunakan masker dan tidak bersalaman sangat menarik untuk diikuti semua kalangan. Adapun gerakan dari senam cegah covid-19 itu terdiri dari 3 sesi. Sesi pertama, pemanasan, gerakan inti dan sesi ketiga adalah pendinginan.

Bentuk pendampingan dilakukan dengan mengevaluasi langsung dari gerakan yang telah dilakukan instruktur (peraga). Kegiatan pengabdian masyarakat ini diharapkan dapat meningkatkan pengetahuan, dan kebugaran jasmani masyarakat. Selain itu pihak pelaksana mampu menjalin hubungan yang lebih baik dengan masyarakat luas agar terjalin kerjasama yang baik dalam upaya promosi kesehatan secara efektif.

\section{Daftar Referensi}

Brick, L. 2007. Bugar Dengan Senam Aerobik. Jakarta :fajar interpratama Offset.

Volume 1, Number 2, Juli 2020 | 11 Maintain Body Fitness in the pandemic with video tutorials Senam Cegah Covid19 (SCC19) with Nusantara Aerobic Nusantara University PGRI Kediri in 2020

Puspodari, Moh. Nur Kholis, Septyaning Lusianti, Setyo Harmono, Dhedy Yuliawan, M. Yanuar Rizky 
GANDRUNG: Jurnal Pengabdian Kepada Masyarakat ISSN: 2721-6136 (Online)

Depdikbud. 1996. Ketahuilah Tingkat Kesegaran Jasmani Anda. Pusat Kesegaran Jasmani dan Rekreasi.

Depdiknas. 2002. Ketahuilah Tingkat Kesegaran Jasmani Anda. Jakarta: Pusat Pengembangan Kualitas Jasmani.

2004. Bugar dan Sehat dengan Berolahraga. Yogyakarta: Andi Offset

Giriwijoyo, S, \& Sidik, D,Z. 2012. IImu Kesehatan Olahraga. Bandung: PT Remaja Rosdakarya

Irianto, D. P. 2004. Pedoman Praktis Berolahraga untuk Kebugaran dan Kesehatan. Yogyakarta: Andi Offset.

Jonni. 2003. Senam Aerobik. Padang, FIK-UNP.

Lutan, R., Hartoto, \& Tomoliyus. 2001. Pendidikan Kebugaran Jasmani Orientasi Pembinaan di Sepanjang Hayat. Jakarta: Depdiknas.

Mukholid, A. 2004. Pendidikan Jasmani dan Olahraga. Jakarta: Yudistira

Sukadiyanto. 2011. Pengantar teori dan metodologi melatih fisik . Yogyakarta: Universitas Negeri Yogyakarta. 